\title{
SISTEM INFORMASI NILAI ONLINE BERBASIS WEB DI SMA NEGERI 20 KABUPATEN TANGERANG
}

\author{
Irfan Nasrullah' ${ }^{1)}$, Saepudin ${ }^{2)}$ \\ 1) Program Study Teknik Informatika Fakultas Teknik \\ Universitas Muhammadiyah Tangerang \\ E-mail: pengembara82@yahoo.co.id \\ 2) Program Study Sistem Informasi \\ STMIK Insan Pembangunan Tangerang \\ E-mail: brat.brash@gmail.com
}

\begin{abstract}
ABSTRAK
SMA Negeri 20 Kabupaten Tangerang merupakan salah satu lembaga pendidikan yang bekerja untuk menciptakan murid-murid yang berahlakul karimah dan berprestasi berdasarkan iman dan takwa. Untuk saat ini fasilitas yang disediakan oleh pihak sekolah sangat membantu siswa dalam proses belajar mereka. Namun disamping fasilitas yang lengkap, SMA Negeri 20 Kabupaten Tangerang masih meiliki kelemahan yang cukup kompleks dalam pengelolaan data, khususnya pengelolaan informasi nilai siswa.

Untuk mengurangi kelemahan tersebut, SMA Negeri 20 Kabupaten Tangerang perlu memiliki sebuah system yang dapat memudahkan guru dan siswa dalam memberikan dan mendapatkan informasi secara mudah dan cepat.Metodologi yang digunakan dalam perancangan system informasi ini menggunakan metode sekuensiel linier (waterfall), metodologi ini dapat digunakan sebagai metodologi untuk menganalisis dan merancang Sistem Informasi Akademik Nilai Siswa Berbasis Web di SMA Negeri 20 Kabupaten Tangerang.Hasil penelitian ini menunjukan bahwa penggunaan Sistem informasi nilai online berbasis web telah mengakomodasi guru dan staf yang bertugas untuk dapat mengelola data-data nilai harian siswa, dengan mudah dapat diakses lewat internet.
\end{abstract}

Kata Kunci: Sistem Informasi, Nilai, Web, Object Oriented Methodology.

\section{PENDAHULUAN}

\subsection{Latar Belakang Masalah}

Teknologi informasi merupakan teknologi yang sedang berkembang pada saat ini, dan merupakan peran penting yang sangat dibutuhkan dalam bidang pendidikan dan di segala aspek kehidupan, sehingga pada akhirnya banyak menimbulkan permasalahan karena membutuhkan sumber daya manusia untuk mendukung hal tersebut.

Di setiap lembaga pendidikan atau sekolah, teknologi informasi sangat menunjang karena mempengaruhi peningkatan dan pemanfaatan informasi dalam segala bidang, salah satunya di SMA Negeri 20 Kabupaten Tangerang yang dimana terdapat suatu penilaian yang belum sepenuhnya menggunakan teknologi informasi dalam kegiatannya sehari-hari khususnya secara online, karena sebagian besar penilaian diakses sekolah menengah kejuruan yang lainnya juga dalam aktifitasnya belum menggunakan teknologi informasi secara penuh dalam arti masih menggunakan komputer yang stand alone yang hanya menghasilkan lebaran-lembaran kertas nilai belum bersifat digital yang diinformasikan melalui internet atau online. Dengan demikian akan lebih efektif bila dibantu dengan teknologi informasi.

Sistem Informasi nilai online merupakan suatu sistem khusus yang digunakan untuk keperluan pengelolaan data-data nilai dengan penerapan teknologi komputer berbasis internet. SMA Negeri 20 Kabupaten Tangerang merupakan salah satu kriteria SMA unggulan yang memiliki sistem akademik. Namun akan lebih sempurna bila 
dilengkapi dengan sistem informasi yang didalamnya menyajikan informasi nilai online bagi siswa-siswi yang ada di SMA Negeri 20 KabupatenTangerang. Dengan sistem yang ada saat ini, untuk mendapatkan informasi seperti mengetahui nilai, berita dan hasil pembagian kelas seorang siswa harus datang kesekolah dan menayakan langsung kepada guru dan pihak administrasi yang bersangkutan dengan pengolahan nilai. Selain itu, dalam kegiatan belajar mengajar, waktu yang diperlukan di kelas sangatlah terbatas karena banyak terpotong oleh libur.

Dalam kegiatannya yang masih manual, maksud manual disini yaitu masih menggunakan aplikasi yang tidak berbasis web seperti Microsoft excel, jadi bisa memperlambat proses informasi, oleh karena itu diperlukan sistem informasi yang memadai untuk menunjang proses pengolahan informasinya agar mempermudah, sehingga pelayanan yang ada lebih menunjang efektifitas dan mudah digunakan.

Dari informasi yang ada, maka dirasakan perlu untuk membangun sebuah web yang dapat memberikan informasi secara lengkap dan dinamis.

\subsection{Batasan Masalah}

Agar pembahasan mencapai sasaran sesuai dengan yang diharapkan serta untuk menghindari terlalu luasnya ruang lingkup pembahasan, maka dalam penelitian ini hanya membahas pada:

a. Data masukan dalam sistem informasi nilai online ini adalah data guru, data siswa, data orang tua, data nilai, dan data mata pelajaran.

b. Sistem informasi nilai online ini diolah oleh seorang admin yaitu Tata Usaha. Pengguna sistem informasi nilai ini adalah guru, siswa, orang tua siswa dan admin.

c. Sistem informasi nilai online ini dibatasi hanya membahas tentang informasi nilai online di SMA Negeri 20 KabupatenTangerang.

d. Memberikan Informasi Untuk Wali Murid tentang nilai-nilai mata pelajaran yang di ikuti siswa selama sekolah

e. Sistem berbasis web dengan metode aliran data terstruktur dan dibangun dengan bahasa pemrograman PHP dan MySql Server sebagai databasenya.

\subsection{Rumusan Masalah}

Masalah yang dibahas dalam hal ini diantaranya:

a. Belum adanya Sistem Informasi Akademik berupa nilai online yang melibatkan interaksi antara siswa dan pihak sekolah itu sendiri.

b. Dalam kegiatannya pengolahan informasi nilai masih manual, maksud manual disini yaitu masih menggunakan aplikasi yang tidak berbasis web seperti Microsoft excel.

c. Administrator yang mengurus informasi nilai harus menunggu melayani siswa yang membutuhkan informasi nilai.

d. Siswa dan Orang tua siswa jika ingin mengetahui informasi nilai harus datang ke sekolah.

\subsection{Tujuan Penelitian}

Adapun tujuan dari penelitian ini yaitu:

a. Bagaimana dalam pengelolahan data informasi nilai, administrator tidak perlu lagi menunggu dan melayani siswa yang membutuhkan informasi nilai.

b. Bagaimana dalam hal siswa dan orang tua jika ingin mendapatkan informasi nila tidak perlu lagi datang ke sekolah.

c. Membuat sistem informasi nilai yang dapat dijadikan sumber promosi dan memberikan informasi (pengumuman) pada pihak interna/maupun eksternal

d. Membantu Orang tua dalam mendapatkan informasi secara cepat tanpa harus berkunjung kesekolah, cukup melaui website tersebut

\subsection{Manfaat Penelitian}

Manfaat dari penelitian ini adalah sebagai berikut:

a. Bagi Penulis

Berguna dalam menambah wawasan pengetahuan baik teori maupun praktik, belajar menganalisa dan merancang sistem informasi nilai siswa berbasis web dan dapat mengambil kesimpulan atau permasalahan yang ada didalam sekolah, khusus-nya pada SMA Negri 20 Kabupaten Tangerang.

\section{b. Bagi Kampus}

Menghasilkan SDM yang berkualitas dalam menganalisa dan merancang sistem informasi yang dibutuhkan bagi sekolah 
sesuai materi yang di dapat di perkuliahan.

\section{c. Bagi SMA Negeri 20 Kabupaten Tangerang}

Hasil penelitian ini diharapkan dapat bermanfaat dan dijadikan sebagai bahan pertimbangan dalam upaya perbaikan masalah yang terkait dalam sistem informasi nilai siswa, sehingga dapat memberikan informasi secara cepat dan tepat.

\section{LANDASAN PEMIKIRAN}

\subsection{Pengertian sistem}

Menurut Raymond McLeod, Jr., George P.Schell diterjemahkan oleh Ali Akbar Yulianto (2010: 10), Sistem Informasi adalah suatu sistem virtual yang memungkinkan manajemen mengendalikan operasi sistem fisik perusahaan pada suatu jaringan kerja dari prosedur-prosedur yang saling berhubungan, berkumpul bersamasama untuk melakukan suatu kegiatan atau untuk menyelesaikan suatu sasaran yang tertentu, dalam suatu urut-urtan operasi klerikal (tulis menulis) biasanya melibatkan beberapa orang didalam satu atau lebih departemen, yang diterapkan untuk menjamin penanganan yang seragam dari transaksi bisnis yang terjadi.

Menurut Kenneth E. Kendall diterjemahkan Thamir Abdul Hafedh Al-Hamdany, B.Sc., M.Sc (2010: 34) mendefinisikan sistem sebegai berikut, Sistem adalah kumpulan dari elemen-elemen yang berinteraksi untuk mencapai suatu tujuan tertentu, dan memproses perubahan atau mentranformasikan input menjadi output.

\subsection{Pengertian Informasi}

Menurut McFadden dkk diterjemahkan oleh Agus Mulyanto (2010: 15) Informasi adalah data yang diolah menjadi sebuah bentuk yang berarti bagi penerimanya dan bermanfaat dalam pengambilan keputusan saat ini atau mendatang.

Munurut Barry $E$, diterjemahkan oleh Agus Mulyanto (2010: 15) informasi merupakan sesuatu yang menunjukan hasil pengolahan data yang diorganisasikan dan berguna kepada orang yang menerimanya.

Menurut Stephen A, Moscove dan Mark G, Simkin dalam bukunya Accounting Informatio System dan diterjemahkan oleh Agus Mulyanto (2010: 15) mengatakan informasi sebagai kenyataan atau bentuk-bentuk yang berguna yang dapat digunakan untuk pengambilan keputusan bisnis.

\subsection{Pengertian Sistem Informasi}

MenurutKenneth E. Kendall dan Julie E. Kendall diterjemahkan Thamir Abdul Hafedh Al-Hamdany (2010: 3) Sistem Informasi adalah informasi yang telah terkomputersasi yang bekerja karena adanya interaksi antara manusia dan komputer yang telah diketahui bahwa informasi merupakan hal yang sangat penting bagi manajemen di dalam pengambilan keputusan, dan informasi diperoleh dari sistem informasi (information system) atau disebut juga dengan processing system atau information processing system atau informationgenering system, yang didefirnisikan sebagai berikut: "Sistem informasi adalah suatu sistem didalam suatu organisasi yang mempertemukan kebutuhan pengolahan transaksi harian, mendukung operasi, bersifat manajerial dan kegiatan strategi dari suatu organisasi dan menyediakan pihak luar tertentu dengan laporan-laporan yang diperlukan."

\subsection{Pengertian Nilai}

Nilai adalah salah satu bagian dari Kegiatan Belajar Mengajar (KBM) di sekolah serta penerapan berbagai cara dan penggunaan beragam alat penilaian untuk memperoleh informasi tentang sejauh mana hasil belajar peserta didik atau ketercapaian kempetensi (rangkaian kemampuan) peserta didik. Hasil nilai menjawab pertanyaan tentang sebaik apa hasil atau presentasi belajar seorang peserta didik. Nilai dapat berupa nilai kualitatif (pernyataan naratif dalam kata-kata) dan nilai kuantitatif (berupa angka).

\section{a. Jenis-jenis Nilai}

1. Nilai Tugas

Nilai tugas yaitu nilai yang diberikan dalam mengerjakan tugas atau sering disebut dengan PR (Pekerjaan Rumah) guna untuk mengingat kembali pelajaran yang diberikan dalam kelas.

2. Nilai Quiz

Nilai Quiz yaitu nilai pengujian materi di sekolah yang diberikan didalam kelas oleh guru dalam pertemuan beberapa kali materi yang di ajarkan oleh guru atau di jelaskan. 
3. Nilai Praktek

Nilai Praktek yaitu nilai pengujian pemahaman dari materi yang di ajarkan oleh guru dan di praktekkan oleh siswa contohnya seperti pelajaran olahraga.

4. Nilai Ujian Tengah Semester (UTS)

Nilai ujian tengah semester yaitu nilai ujian dari pembelajaran selama setengah berjalan di sekolah yang di uji dalam bentuk UTS (Ujian Tengah Semester) yang dilakukan oleh semua sekolah.

5. Nilai Ujian Akhir Semester (UAS)

Nilai ujian akhir semester yaitu nilai ujian dari pembelajaran selama setahun berjalan di sekolah yang diuji dalam bentuk UAS (Ujian Akhir Semester) yang dilakukan oleh semua sekolah.

6. Nilai Raport

Nilai Rapor merupakan perhitungan nilai yang di gunakan untuk menghitung secara otomatis nilai rapor setiap siswa. Aturan ini berupa pemberian bobot-bobot untuk setiap jenis pengujian yang digunakan dalam pelajaran, misalnya $10 \%$ untuk kehadiran siswa, $20 \%$ untuk tugas, 30\% untuk UTS, 40\% untujk UAS.

\subsection{Pengertian Website}

Website adalah salah satu aplikasiyang berisikan dokumen-dokumen multimedia (teks, gambar, suara, animasi dan video) di dalamya yang menggunakan protocol HTTP (Hypertext transfer protocol) dan untuk mengaksesnya menggunakan perangkat lunak yang disebut browser.

Di kalangan web ada dua istilah profesi yaitu web designer dan web programmer.Web designer adalah orang yang bertugas untuk mendesign web, sedangkan web programmer adalah orang yang bertugas untuk menuliskan skrip pemrograman web untuk sebuah situs.

Tahap-tahap membuat membangun sebuah situs yang harus diperhatikan yaitu:

a. Memilih dan mempersiapkan too/ Mendesign web

b. Mempersiapkan database server

c. Pemrograman web

d. Menggabungkan desain dan pemrograman web

e. Mengevaluasi situs

f. Proses upload file dan database

g. Mempromosikan suatu produk

Ditinjau dari aspek content atau isinya, web dapat dibedakan menjadi 2 jenis, yaitu:

\section{1) Web statis}

Web statis adalah web yang isinya atau content tidak dapat berubah-ubah. Maksudnya adalah isi dari dokumen web tersebut tidak dapat diubah secara cepat dan mudah.

2) Web Dinamis

Web dinamis adalah jenis web yang content/isinya dapat berubah-ubah setiap saat.

\section{METODOLOGI PENELITIAN}

\subsection{Obyek Penelitian}

Obyek penelitian yang dibahas dalam penulisan ini mengenai Sistem Informasi Nilai di SMA Negeri 20 Kabupaten Tangerang

\subsection{Tempat Penelitian}

Tempat penelitian adalah, tempat dimana peneliti melakukan suatu kegiatan yang bertujuan untuk memperoleh data yang berhubungan dengan Sistem Nilai Online. Penelitian ini dilaksanakan dilingkungan Sekolah SMA Negeri 20 Kabupaten Tangerang, tempat penelitian ini beralamatkan di:

Alamat: Jl. Raya K.H Sa'adulah KM.2 Kp. Empetan Ds. Buaran Bambu Kec. Pakuhaji Kabupaten Tangerang.

Tlp.: (021) 95227834

\subsection{Metode Pengumpulan Data}

Dalam metode pengumpulan data peneliti melakukan beberapa metode untuk mendapatkan data dan informasi yang nyata. Berikut metode yang dilakukan dalam pengumpulan data sebagai berikut:

\subsubsection{Jenis dan Metode Pengumpulan Data}

Adapun jenis dan metode pengumpulan data yang penulis gunakan saat melakukan penelitian di Sekolah SMA Negeri 20 Kabupaten Tangerang ini adalah:

\section{a. Sumber Data Primer}

Sumber data Primer adalah data atau segala informasi yang diperoleh dan didapat oleh penulis langsung dari sumber sumber, baik sumber individu maupun sekelompok bagian dari objek penelitian seperti hasil dari Wawancara dan Observasi langsung pada objek yang diteliti dalam hal ini yaitu data yang didapat dari Sekolah SMA Negeri 20 Kabupaten Tangerang. 


\section{1) Wawancara}

Wawancara merupakan Metode pengumpulan data melalui tatap muka dan Tanya jawab langsung mengenai jalannya Sistem Informasi Nilai yang ada di Sekolah SMA Negeri 20 Kabupaten Tangerang. Wawancara dilakukan antara peneliti dengan pihak bagian yang terkait dengan sistem Informasi Penilaian yang sedang berjalan.

2) Observasi

Observasi merupakan Metode pengumpulan data melalui pengamatan dan pencatatan oleh peneliti terhadap gejala / peristiwa yang diteliti pada objek penelitian dalam hal ini adalah Sekolah SMA Negeri 20 Kabupaten Tangerang

\section{b. Sumber Data Sekunder}

Sumber data Sekunder yaitu data Primer yang telah diolah lebih lanjut dan disajikan dengan baik oleh pengumpul data primer atau pihak lain. Data sekunder dapat berupa tabel-tabel atau diagram dan juga segala informasi yang berasal dari literature yang ada hubungannya dengan teori-teori mengenai topik penelitian yang didapat dari Sekolah SMA Negeri 20 Kabupaten Tangerang. Sumber data sekunder dapat berupa data Dokumentasi, yaitu data yang diperoleh oleh peneliti dengan membaca buku-buku di perpustakaan dan mencari referensi yang berkaitan dengan masalah yang akan dibahas oleh penulis seperti transkrip, mesin pencarian maupun dokumen seperti skripsi dll.

\subsection{Metode Analisis Data}

Metode analisis data menggunakan teknik dan alat bantu sebagai berikut:

a. UML (Unified Modelling Language)

Peneliti akan mempelajari terlebih dahulu UML pada sistem perhitungan caddie fee tersebut untuk mengidentifikasi kelemahan dari sistem yang akan dijadikan perbandingan terhadap masalah yang terjadi.

b. Aktor dan use case Diagram

Aktor adalah pihak yang terlibat didalam sistem. Pihak-pihak yang terkait hendaknya memiliki peran didalam sistem. Use case digunakan untuk menjelaskan fungsi yang ada didalam suatu sistem berupa komponen, kejadian atau kelas yang saling berinteraksi didalam sistem.

\section{c. Class diagram}

Class diagram merupakan kumpulan kelas-kelas objek. Class diagram yang baik menghasilkan suatu rancangan sistem atau program yang mendekati kenyataan.

\section{d. Sequence diagram}

Sequence diagram menggambarkan interaksi antar objek didalam dan message yang digambar terhadap waktu.

\section{e. Activity diagram}

Activity diagram menggambarkan berbagai alir aktivitas dalam sistem yang sedang dirancang, bagaimana masing-masing alir berawal, decision yang mungkin terjadi, dan bagaimana mereka berakhir.

\section{f. Kamus Data}

Menggambarkan katalog fakta tentang data dan kebutuhan-kebutuhan informasi dari suatu sistem informasi. Dengan kamus data analisis sistem dapat mendefinisikan data yang mengalir di sistem dengan lengkap.

g. Rancangan Input dan Output

Menggambarkan hasil akhir dari rancangan yang dibuat.

\subsubsection{Metode Pendekatan dan Pengembangan Sistem \\ Metode Pendekatan Sistem merupakan} salah satu cara penyelesaian persoalan yang dimulai dengan dilakukannya identifikasi terhadap adanya sejumlah kebutuhan-kebutuhan, sehingga dapat menghasilkan suatu operasi dari sistem yang dianggap efektif. Sedangkan Metode Pengembangan Sistem terdiri dari sederetan kegiatan yang dapat dikelompokan menjadi beberapa tahapan, yang membantu kita dalam pengembangan sistem yaitu:

\section{a. Metode Pendekatan Sistem}

Merupakan pendekatan mengenai bagaimana menggunakan alat-alat dan peraturan-peraturan yang melengkapi satu atau lebih tahapan-tahapan pengembangan Sistem Informasi. Pendekatan Sistem yang digunakan oleh penulis adalah Perancangan terstruktur, yaitu penjelasan terstruktur yang dipusatkan pada penjelasan tentang hubungan antar bagian. Model analisis harus dapat mencapai 3 sasaran utama yaitu menggambarkan kebutuhan pengguna, membangun dasar pembuatan desain perangkat lunak dan membatasi serangkaian persyaratan yang dapat di validasi ketika perangkat lunak selesai dibangun. 
Adapun Metode Pendekatan Sistem yang digunakan adalah Metode berorentasi pada data yaitu analisis dan perancangan terstruktur.

\section{b. Metode Pengembangan Sistem}

Metode Pengembangan Sistem merupakan kesatuan metode-metode, prosedur, konsep dan aturan - aturan yang digunakan untuk menyusun suatu sistem yang baru sebagai pengganti sistem yang lama secara keseluruhan atau memperbaiki sistem yang telah berjalan.

Metode yang digunakan dalam perancangan sistem ini yaitu menggunakan model waterfall. Metode waterfall terdiri dari system engineering, analysis, design, coding, testing, dan maintenance.

\section{ANALISA DAN PEMBAHASAN}

\subsection{Prosedur Sistem Berjalan}

Berikut ini yang penulis analisa mengenai proses penyampaian informasi nilai yang sedang berjalan pada SMA Negeri 20 Kabupaten Tangerang. Prosedur sistemnya sebagai berikut:

a. Siswa mengikuti Ulangan harian,ujian tengah semester (UTS), ujian akhir semester (UAS).

b. Guru mengkoreksi hasil jawaban tersebut dan akan menghasilkan nilai, lalu menyerahkan nilai tiap-tiap siswa kepada pihak Tata usaha (TU).

c. Tata Usaha membuat laporan nilai untuk dijadikan sebuah informasi nilai yang akan di umumkan melalui papan pengumuman.

\subsection{Sistem yang sedang berjalan saat ini}

Untuk menganalisa sistem yang berjalan, pada penelitian ini digunakan program unified modeling language (UML) untuk menggambarkan prosedur dan proses yang sedang berjalan saat ini, sebagai berikut:

\section{a. Usecase diagram}

Use case diagram menggambarkan fungsionalitas yang diharapkan dari sebuah sistem. Yang ditekankan adalah "apa" yang diperbuat sistem, dan bukan "bagaimana". Sebuah usecase mempresentasikan sebuah interaksi antar actor denngan sistem.

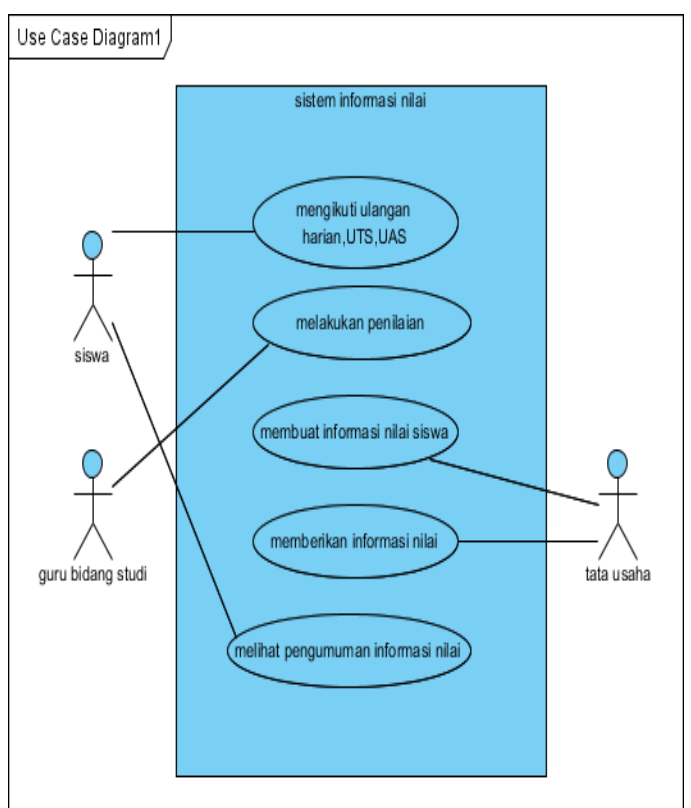

Gambar Use Case Diagram yang berjalan.

\section{b. Activity Diagram}

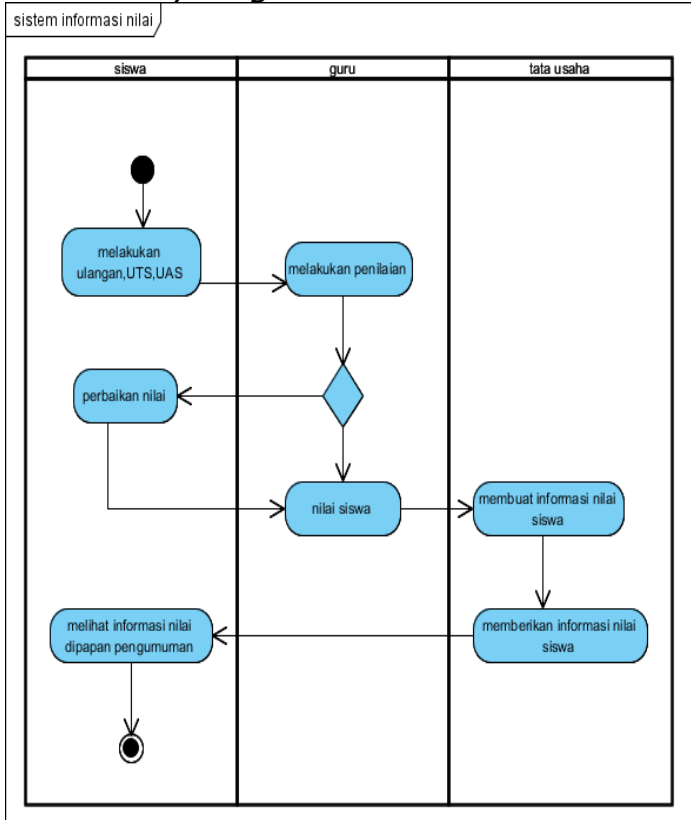

Gambar Activity Diagram yang berjalan

\subsection{Evaluasi system yang sedang berjalan}

Evaluasi sistem yang berjalan bertujuan untuk mengetahui masalah-masalah yang terjadi sehingga dihasilkan pemecahan masalah terhadap masalah-masalah yang dihadapi.

Adapun evaluasi sistem informasi nilai akhir semester yang sedang berjalan di SMA Negeri 20 Kabupaten Tangerang, antara lain: 
Tabel Evaluasi Sistem Yang Berjalan

\begin{tabular}{|c|c|c|}
\hline No & Masalah & $\begin{array}{c}\text { Pemecahan } \\
\text { Masalah }\end{array}$ \\
\hline 1 & $\begin{array}{l}\text { Pencarian data } \\
\text { nilai memerlukan } \\
\text { waktu yang lama } \\
\text {,hal ini disebabkan } \\
\text { karena } \\
\text { penyimpanan data } \\
\text { nilai masih } \\
\text { menggunakan } \\
\text { dokumen berupa } \\
\text { kertas yang tidak } \\
\text { terjamin } \\
\text { keamanannya }\end{array}$ & $\begin{array}{l}\text { Dibutuhkan } \\
\text { adanya system } \\
\text { informasi nilai } \\
\text { berbasis } \\
\text { web,yang } \\
\text { bertujuan untuk } \\
\text { pencarian data } \\
\text { nilai secara } \\
\text { cepat,tepat dan } \\
\text { mudah, serta } \\
\text { dapat menjamin } \\
\text { keamanannya } \\
\text { karena media } \\
\text { penyimpanan } \\
\text { data menggunakan } \\
\text { database }\end{array}$ \\
\hline 2 & \begin{tabular}{ll}
\multicolumn{2}{l}{ Penyampaian } \\
informasi nilai \\
hanya bisa \\
didapatkan oleh \\
siswa dan orang \\
tua siswa dengan \\
datang langsung \\
ke sekolah
\end{tabular} & $\begin{array}{l}\text { Dibutuhkan } \\
\text { adanya system } \\
\text { informasi nilai } \\
\text { berbasis web, } \\
\text { yang dapat } \\
\text { memudahkan } \\
\text { siswa dan } \\
\text { orangtua siswa } \\
\text { dalam } \\
\text { memperoleh } \\
\text { hasil nilai yang } \\
\text { di butuhkan }\end{array}$ \\
\hline
\end{tabular}

\subsection{Rancangan Usulan}

a. Use Case Diagram yang Diusulkan Untuk Admin

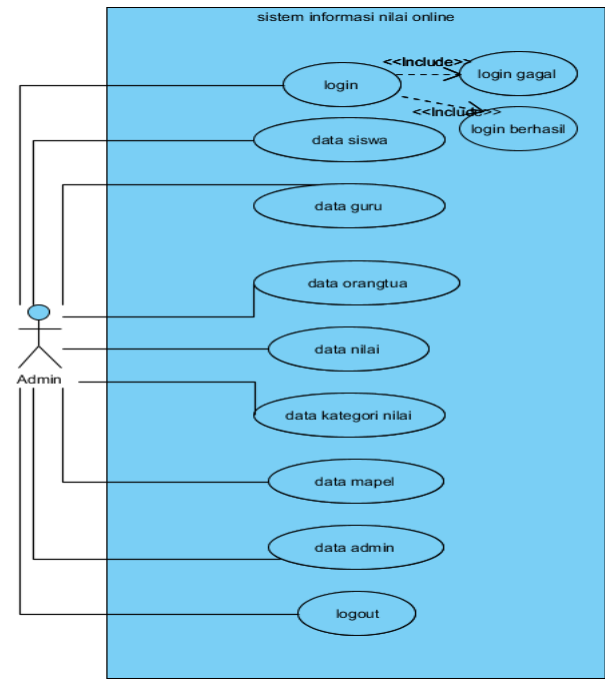

Gambar Use Case Diagram yang diusulkan untuk admin.

\section{b. Use Case Diagram yang Diusulkan Untuk Guru}

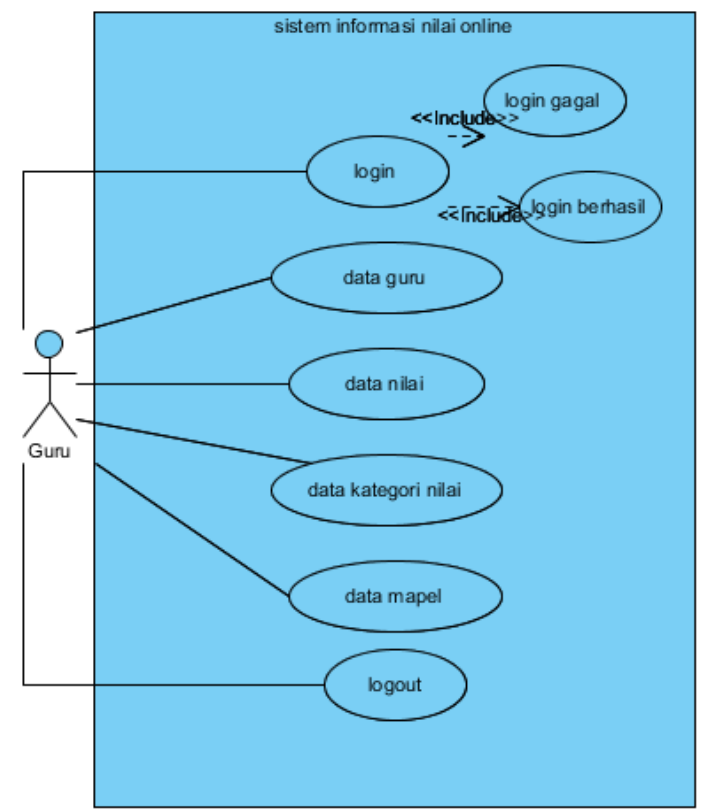

Gambar Use Case Diagram yang diusulkan untuk guru

\section{c. Use Case Diagram yang Diusulkan Untuk Siswa}

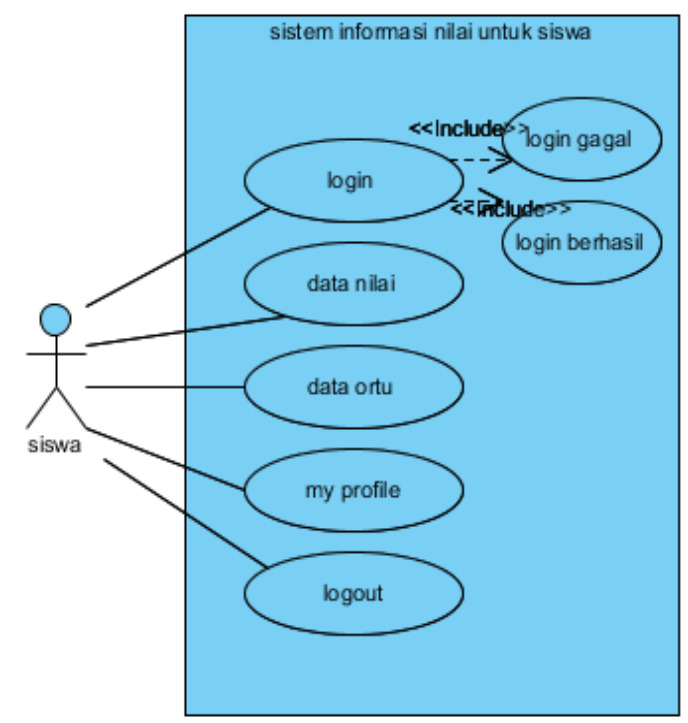

Gambar Use Case Diagram yang diusulkan untuk siswa 
d. Use Case Diagram Yang Diusulkan Untuk Orang Tua

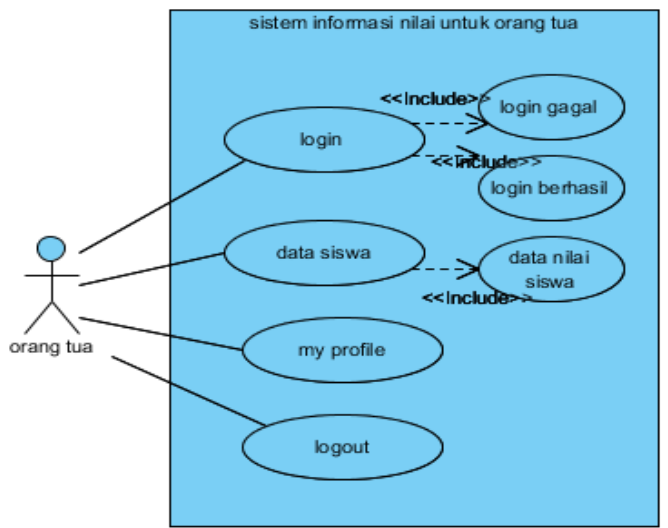

Gambar Use Case Diagram yang diusulkan untuk orang tua

\section{e. Activity Diagram login user}

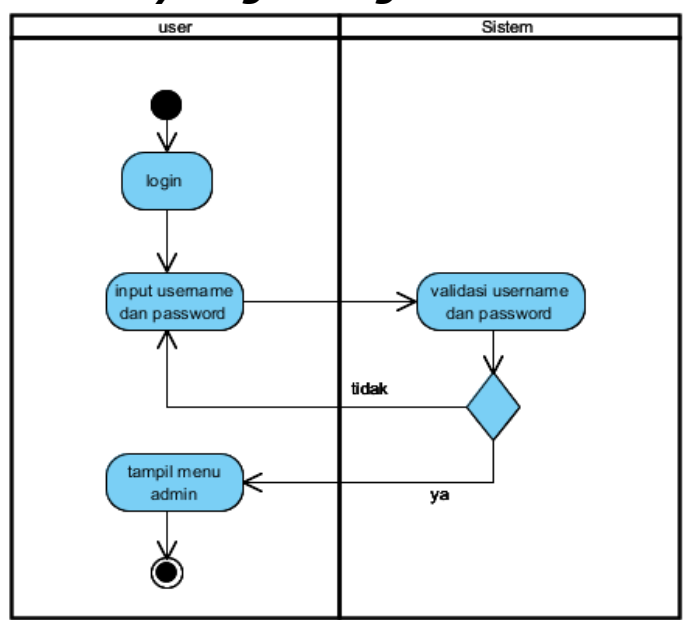

\section{f. Activity Diagram Informasi nilai}

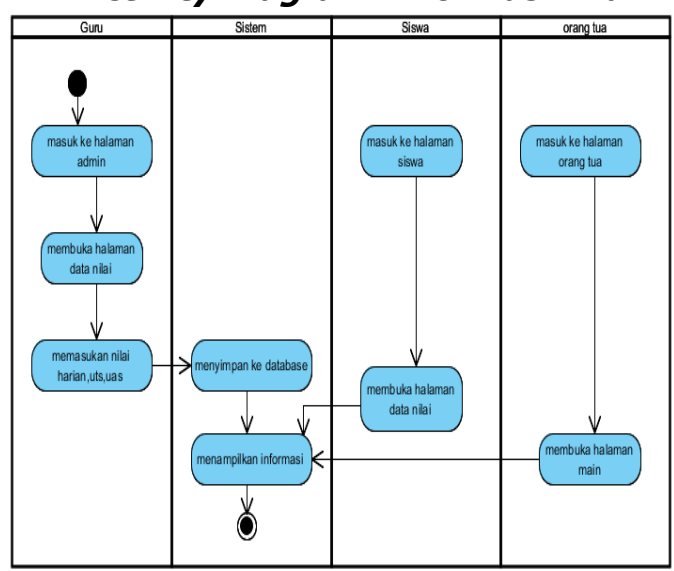

g. Activity Diagram masukan data siswa Untuk Admin

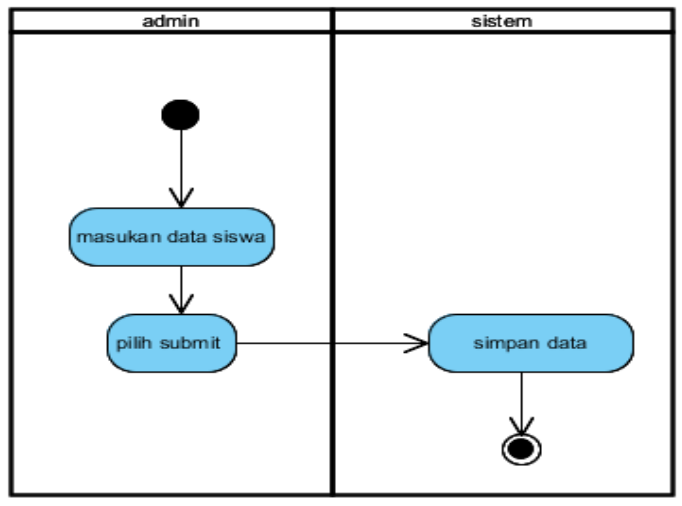

h. Activity Diagram Masukan Data Orang Tua Untuk Admin

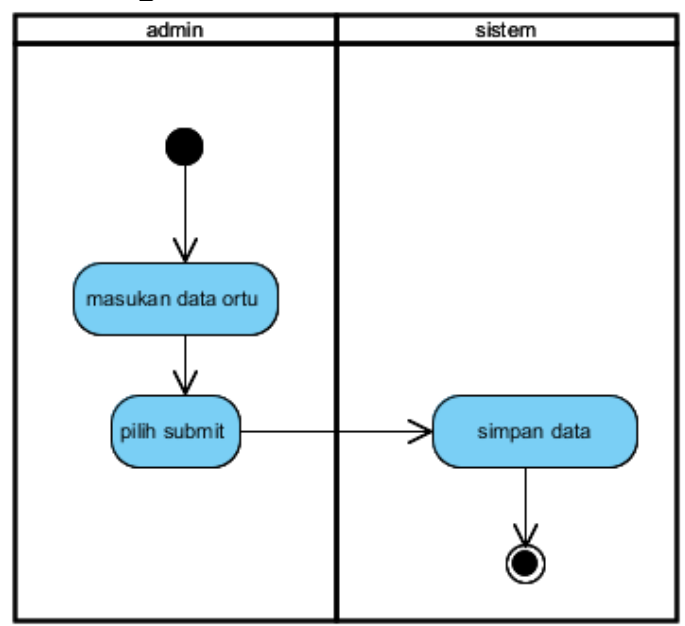

i. Activity Diagram Masukan Data Guru Untuk Admin

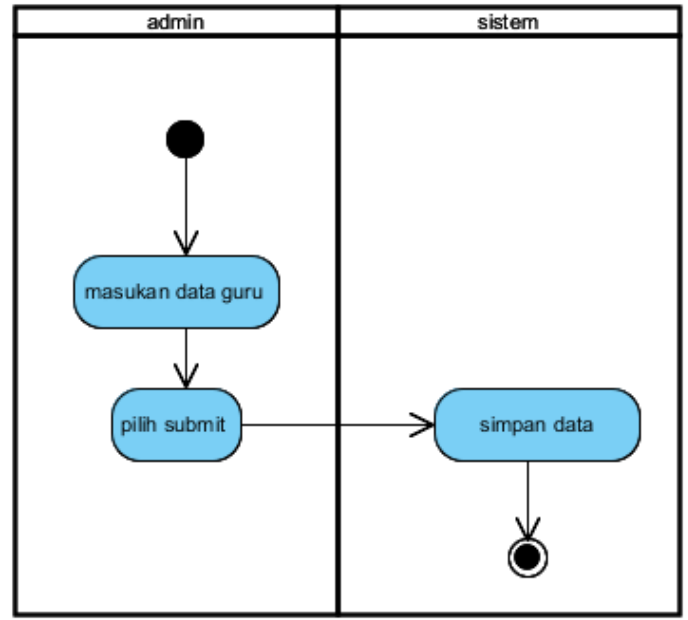




\section{j. Sequence Diagram}

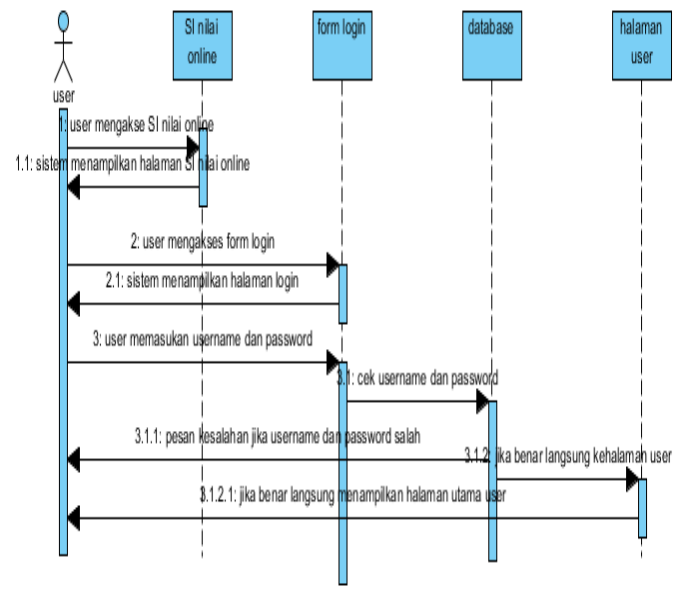

Gambar Sequence Diagram Login User

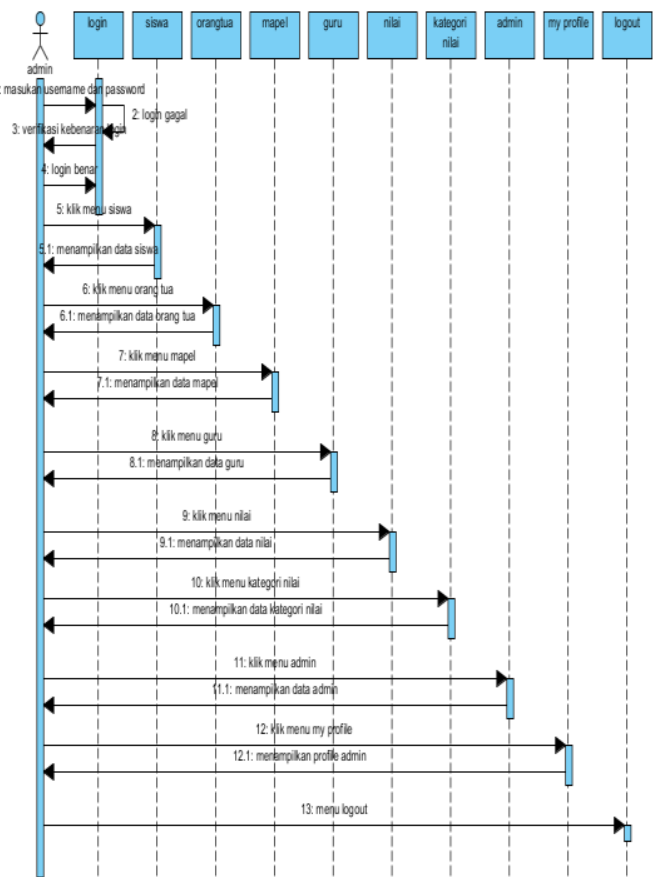

Gambar Sequence Diagram yang diusulkan untuk admin.

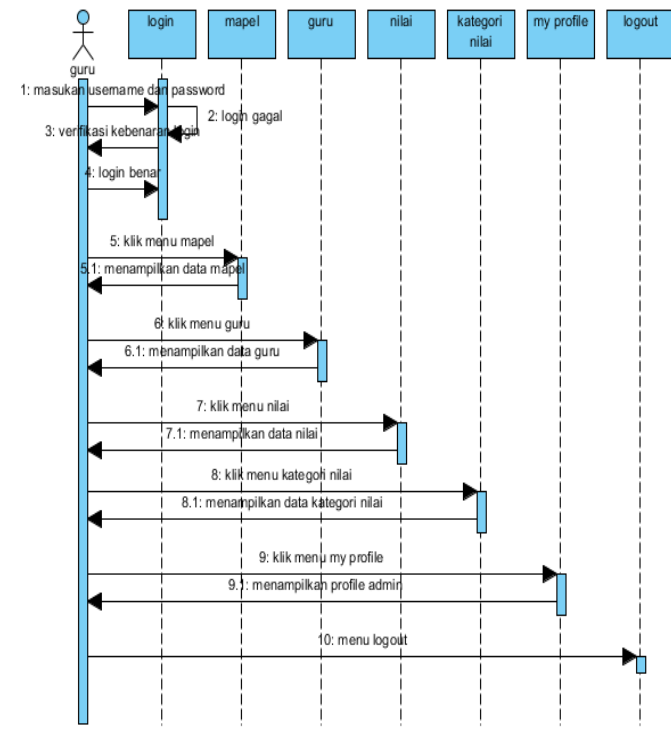

Gambar Sequence Diagram yang diusulkan untuk Guru

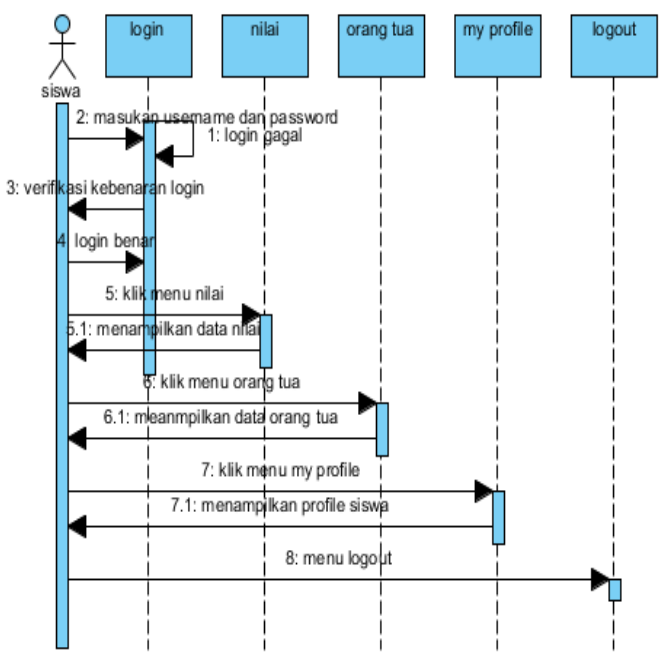

Gambar Sequence Diagram yang diusulkan untuk siswa

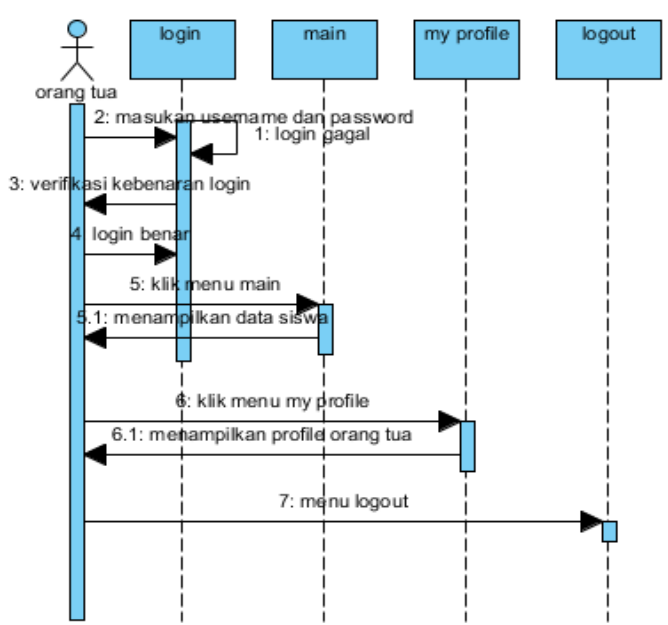

Gambar Sequence Diagram Yang Diusulkan Untuk Orang Tua. 


\section{k. Class Diagram}

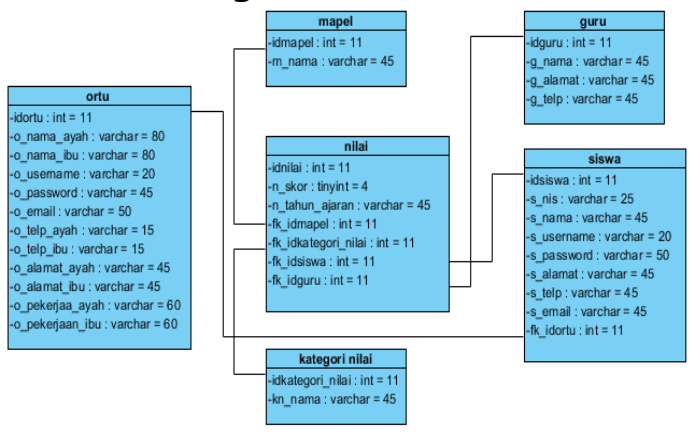

Gambar Class Diagram yang diusulkan

\subsection{Tampilan Sistem}

a. Tampilan Sistem pilihan Login User

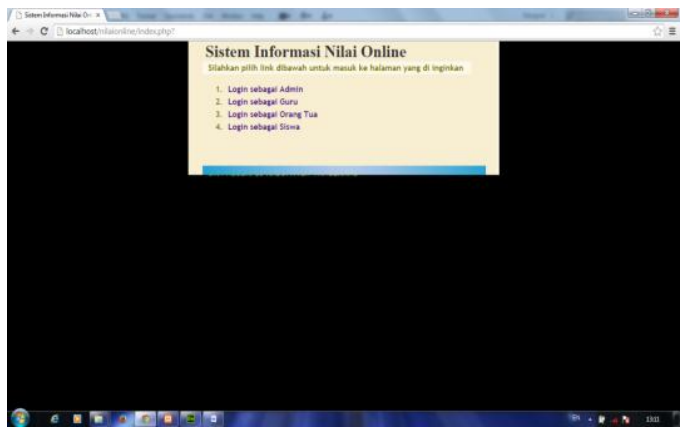

Gambar Tampilan Layar Pilihan Link User

\section{b. Tampilan Sistem Login User}

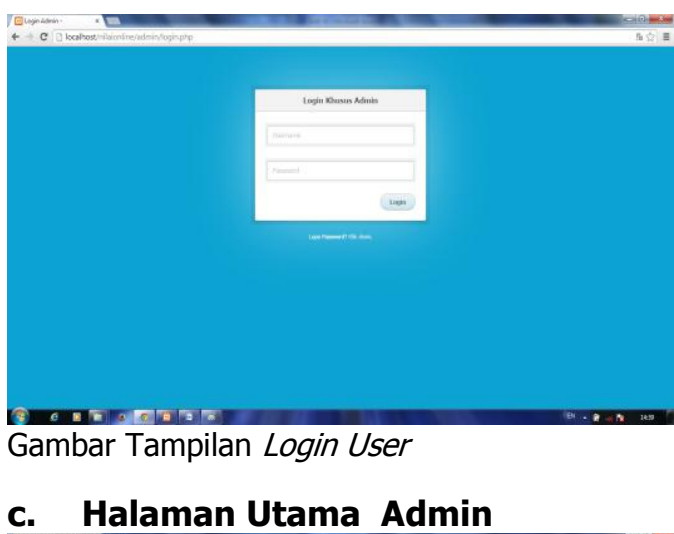

\section{c. Halaman Utama Admin}

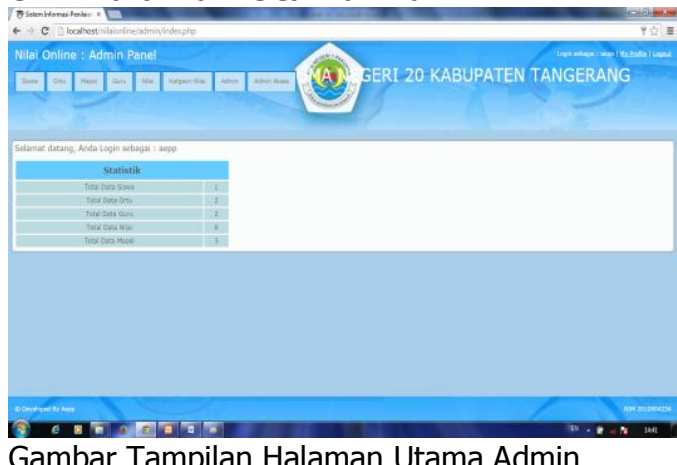

\section{d. Halaman Menu Siswa}

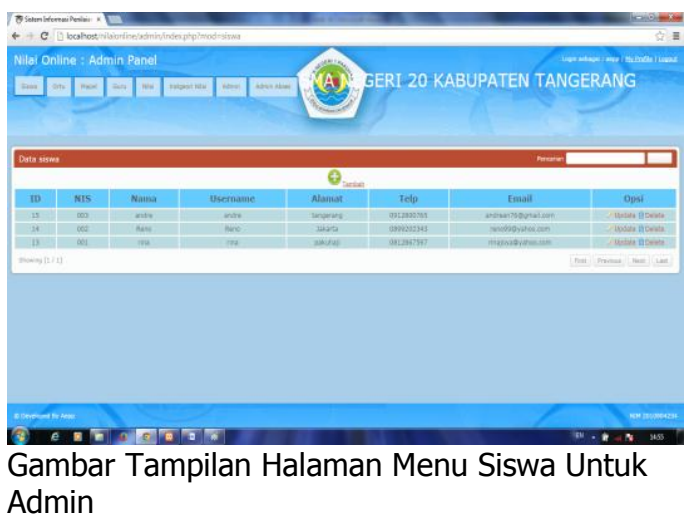

\section{e. Halaman Menu Guru}

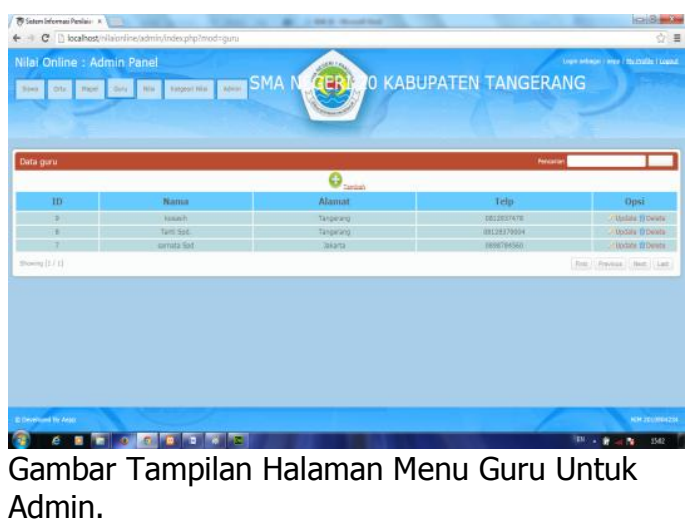

\section{f. Halaman Menu Nilai}

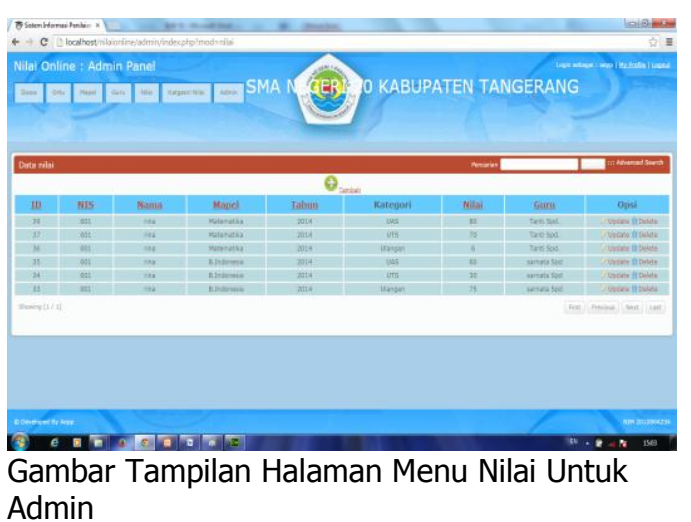

\section{g. Halaman Menu Admin}

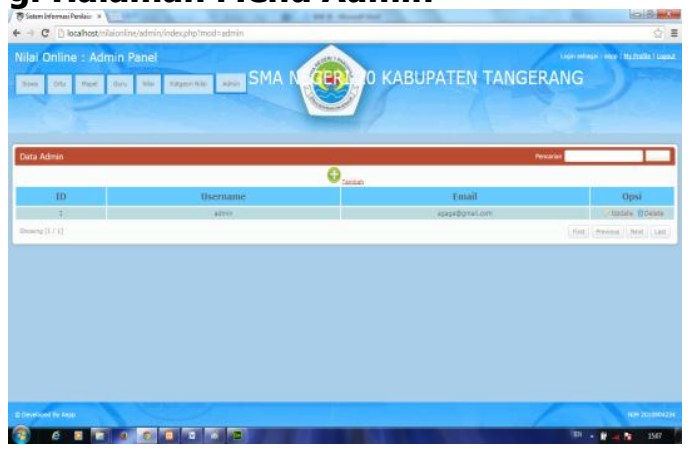


Gambar Tampilan Halaman Menu Admin

\section{h. Halaman Menu My Profile}

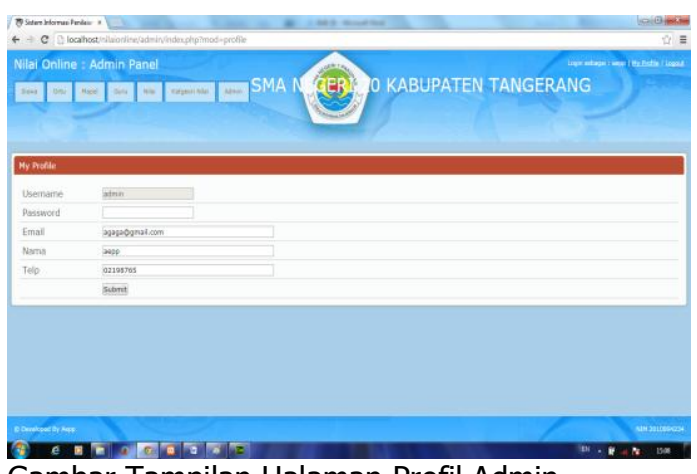

Gambar Tampilan Halaman Profil Admin

\section{i. Halaman Menu nilai}

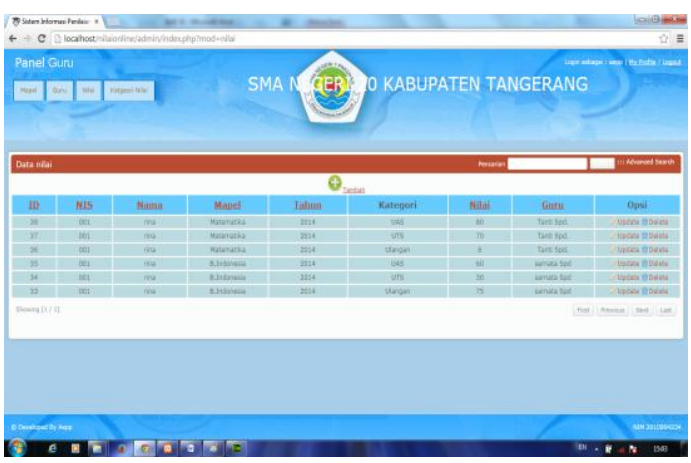

Gambar Tampilan Halaman Menu Nilai Untuk Guru

\section{KESIMPULAN}

Berdasarkan analisis dan perancangan dari Sistem Informasi Nilai Online Berbasis Web pada lembaga pendidikan SMA Negeri 20 Kabupaten Tangerang, maka dapat disimpulkan beberapa hal sebagai berikut:

a. Penggolongan user menjadi 4 bagian (Tata Usaha, Guru, Siswa, Orang tua) dengan batasan akses tertentu dapat dikatakan pula sebagai pembagian hak, wewenang dan kewajiban user yang bersangkutan

b. Dikarenakan system informasi ini merupakan sebuah aplikasi berbasis web, maka system informasi ini dapat dipublish melalui jaringan internet

c. Pembangunan sistem informasi ini dapat membantu kepada guru untuk menyampaikan nilai kepada siswa menjadi lebih cepat dan lebih optimal sehingga dapat diakses dimanapun dan kapanpun

\section{REFERENSI}

Al-Fatta, Hanif (2011). Analisis dan Perancangan Sistem Informasi untuk Keunggulan Bersaing Perusahaan dan Organisasi Modern. Yogyakarta: Andi Offset.

Al-Jufri, Hamid. (2011). Pengertian Sistem. Jakarta: Mitra Wacana Media.

Al-Jufri, Hamid. (2011). Sistem Informasi Manajemen Pendidikan. Jakarta: Smart Grafika.

Jogiyanto. (2010). Analisa dan Design. Yogyakarta: Penerbit: Andi.

As, Rosa dan shalahudin, M. (2011). Rekayasa Perangkat Lunak. Bandung: Modula Bandung.

Sucipto (2011). Konsep dan Teknik Pengembangan Sistem Berbasis Teknologi Informasi.Banten: Dinas Pendidikan Propinsi Banten.

Talib, Haer. (2011). Panduan Praktis Menguasai Komputer.Jakarta: Elex Media Komputindo.

Tantra, Rudy (2012). Manajemen Proyek Sistem Informasi. Yogyakarta: Andi Offset

Widodo, Pudjo, Prabowo. dan Herlawati. (2011). Menggunakan UML. Bandung: Informatika. 